\title{
Children's problem solving skills: Does Drama Based Storytelling Method work?
}

\author{
Gökhan Kayılı', Zeynep Erdal²
}

\begin{abstract}
This research aims to investigate the effect of Problem Solving Training provided through the Drama Based Storytelling Method on the problem solving skills of five-year-old children. Within the context of quantitative methodology, pretest-posttest control group quasi-experimental design was employed in the study. Forty children, 20 in the experimental and 20 in the control group, were included in the research. In addition to the National Education Preschool Education Program, children in the experimental group were given problem solving training with Drama Based Storytelling Method one hour 2 days a week for 7 weeks. Children in the control group were not included in this education, but continued their daily education programs within the scope of Ministry of Education Preschool Education Program. The problem solving skills of the children participating in the research were measured using the Scale of Problem Solving Skills. The test was administered to children before and after the intervention period. In addition, it was read ministered to the experimental group 2 weeks later. Results suggest that the problem-solving education provided with the Drama Based Storytelling Method, which is implemented in combination with the National Preschool Education Program, has contributed positively to the problem-solving skills of five-year-old children.
\end{abstract}

\section{Article History}

Received: 30 September 2020

Accepted: 29 December 2020

\section{Keywords}

Preschool; Drama;

Storytelling; Problem

solving skills

\section{Introduction}

Described as the golden age of childhood, preschool is a period when various skills are acquired and develop. Basic problem solving skills, one of the most distinctive features of this period once the foundations of development have been laid, can be developed with the experiences gained and the programs implemented. Educational opportunities and activities offered to help build problem solving skills enable children to recognize problems, produce possible solutions to the problems they encounter, and as a result, enable them to establish a cause-effect relationship between events.

Definitions vary on the problem solving skill and Heppner's (1987) definition differs from other definitions in certain aspects in studies dealing with this issue. According to Heppner, problem solving has the same meaning as the concept of dealing with problems. Personal problem-solving skill is defined as directing cognitive and emotional processes to a target in order to make behavioral reactions with the aim of adapting to internal or external demands in real life. Based on this, it should be ensured that the teacher and the student use problem solving skills in order to develop all the features of the mind in the education process, students should be given problems appropriate to their level taken from life and then they should be asked to produce alternative solutions and to review possible results. If the educational environment is organized based on this philosophical idea, students will grow up to be individuals that have problem-solving skills (Çavuş, 2004).

With social problem-solving skills, children learn to be in good relationships with their friends and to be responsible for their behaviors by developing the skills necessary to communicate effectively with

${ }^{1}$ Selcuk University, Faculty of Health Sciences, Department of Child Development, Konya, Turkey, e-mail: gokhankayili@selcuk.edu.tr, ORCID: https://orcid.org/0000-0001$\underline{7959-4128}$

2 Ministry of National Education, Kemal Rızvanoglu Primary School, Konya, Turkey, e-mail: erdal.zeynep@hotmail.com, ORCID: https://orcid.org/0000-0001-6159-5632 
their environment. In addition, thanks to this skill, children are able to understand their own emotions and the emotions of others and look at events from the perspective of others (Bingham, 1998; Shure, 2001). Especially children with attention deficit and hyperactivity disorder, who act impulsively and tend to be aggressive, are likely to experience social problem solving difficulties. This type of children behave aggressively, lacking an empathic perspective and acting without thinking about the non-aggressive solution. It is stated that children with problem-solving skills play more constructive games, are liked more by their peers, and exhibit more cooperative behaviors at home and at school (Webster-Stratton, 2012).

Children mature and develop greatly in social problem solving during their school years. Around the age of seven, children tend to display prosocial behaviors, such as relying on friendly persuasion and compromise, rather than on antisocial behaviors like tugging, hitting, or insisting that the other child conforms to them, thinking about alternatives when their first strategy doesn't work, and resolving conflicts without adult intervention. However, children aged five cannot think that problem-solving behaviors will affect the future of their relationships. This is also related to their cognitive maturity (Mayeux \& Cillessen, 2003; Yeates, Schultz, \& Selman, 1991).

Problem solving is a very important skill for individuals to cope with life's problems and adapt to life. As the individual ages, the conditions and environmental factors change over time and the problems they encounter become more complex. For this reason, individuals should gain problem solving skills in early childhood because if they cannot manage the problems and find solutions as they get older, they lose their self-confidence and are more likely to lead an unhappy life. A society of such individuals is in danger and can fall apart. Only people with the necessary problem-solving skills can lead the society to a better future. Thus, considering that problem solving skill not only affects the individual's own abilities but also the society in which s/he lives, the necessary importance should be given to solving social problems. One of the questions that arise here is whether problem solving is an innate skill, or whether it is gained later by various methods. However, Kneeland (2001) has stated that in fact there are not many people with sufficient training to master this skill.

Intervening children with poor social problem-solving skills supports development in various ways. Effective social problem solving allows children to successfully cope with stressful life situations, as well as the development of peer relationships. In addition, it reduces the risk of adjustment difficulties in disadvantaged children from families with low socioeconomic status (Goodman, Gravitt, \& Kaslow, 1995). Readily accessible in the literature, intervention programs that support social problem-solving in children have made positive contributions to children's development (Bash \& Camp, 1985; Battistich, Schaps \& Wilson, 2004; Beelmann, Pfingste, \& Lösel, 1994; Brown, Odom, \& McConnell, 2008; Durlak, Weissberg, Dymnicki, Taylor, \& Schellinger, 2011; Goldstein \& Pentz, 1984; Schneider, 1992; Shure, 2001; WebsterStratton, 2012; Weissberg, Kumpfer, \& Seligman, 2003).

The most effective and correct use of mental processes can only be achieved with a qualified education program. Various methods and techniques are included by enriching the contents of the educational programs in order for children to find alternative solutions to their problems (Clark, Cuthbert, Lewis-Fernández, Narrow, \& Reed, 2017). When these methods and techniques are applied at certain time intervals, they contribute to the skill acquisition of children. These include social problem solving education with direct teaching approach, social problem solving education based on cognitive process approach, collaborative learning method, peer-mediated teaching method, modeling and video modeling method, role playing technique, coaching, homework and drama method (Gardner, Cartledge, Seidl, Woolsey, \& Schley, 2001; Webster-Stratton, 2012; Webster-Stratton \& Reid, 2004;). The Drama Based Storytelling Method, which is used as an intervention method in the research, includes most of these methods with its eclectic perspective.

Especially in recent years, stories and drama have attracted great attention among the methods used in the development of problem solving skills. The origin of the word "story" comes from the word "mesel" in Arabic, and the history of its literal usage today is quite recent. Instead of this term, which has a history of 130 years, words that have their own meaning such as parable, epic and story were previously used. 
The "mesel" form of the word, which will turn into a "story" over time, began to appear from the beginning of the 19th century, thus, a new meaning is loaded in addition to its old meaning of "mesel" (Sakaoğlu, 2016). "Story" in the dictionary of Turkish Language Association is defined as "the literary genre, which is generally created by the folk, based on imagination, living in an oral tradition, mostly describing the extraordinary events experienced by humans, animals and beings such as witches, gnomes, giants and fairies (Ministry of National Education [MoNE], 2013). The Boratav defines story as a short narrative spoken in prose, independent of religiosity and magic, beliefs and customs, completely imaginary, unrelated to reality and without any pretense to make anyone believe what it tells. According to him, the main feature that distinguishes the story from the legend and the epic, no matter what kind of story it is, is that it is a type of narration that gives the impression of the creation of dreams (Boratav, 2019).

Stories and fairy tales foster children's imagination and act as a bridge between the fantasy world and the real world. From stories, children notice the acceptable and unacceptable behaviors of the society they live in, and learn how to adapt them to their own life when they encounter problems arising from these behaviors especially in the preschool period. Children also learn how to produce solutions in these negative situations since the events and characters encountered are advisory. We can say that stories that contain all these features have many advantages such as increasing vocabulary knowledge, developing attention and problem solving skills, and establishing cause - effect relationships. Today, based on these advantages, stories provide creation of awareness by combining their strengths with effective methods that can improve children's skills.

Drama, one of the most effective methods used to create awareness, has been included in educational activities for many years (Bolton, 2007; Webster, 2010). Drama, with its inclusion in education, beginning in England and America in the 20th century, is currently either used as a teaching method to teach certain subjects in schools of many educational levels or included in the programs as a stand-alone course (Powell, 2020; Sağlam, 1997). Adıgüzel (2013) and Szecsi (2008) defines drama as: “Activities with actions inside that include internal and external movements in which one or more people interact with each other, the nature or other objects and their life situations to a large extent.". Preschool drama is an activity that aims to help the childlearn by doing and experiencing and supports all developmental areas.It has predetermined goals, is based on expressing events with verbal or non-verbal communication methods, and includes animations (Ministry of National Education [MoNE], 2013).

Practicing by giving the child an active role around a certain story ensures more effective learning in the educational drama, which is seen to be a valuable learning tool as one type of drama. Therefore, stories can be considered among the techniques that are frequently used in the drama method. According to Önder (2016), role-playing, the most basic technique of educational drama, has a quality that runs mental processes by putting oneself in another's place in her mind. The child can evaluate himself in different situations by acting different roles in role playing. Thus, role-playing contributes to the child on development of self-perception, language development, knowledge of rules and empathy positively. In Preschool Education Program prepared by the MoNE (2013), it is emphasized how important it is to carry out drama activities and include dramatic play centers in classrooms while planning daily activities. Since drama practices are used in preschool education plans for educational purposes, children can recognize their own identity and body by the help of drama, maintain harmonious relationships with the people living around and the group they work in, produce new ideas and find different solutions to problems. Also in the drama, attention should be paid to the acquisition rather than the artistic dimension in roleplays. Creative thinking skills develop and permanent learning occurs when questions like who, what, why, when, how, and where are prioritized in drama activitiesand the activities are prepared within this framework (Erdoğan, 2019; Ritter \& Mostert, 2017).

In ancient times, people used to tell stories to convey their experiences to other people and to spread the beliefs of society.Accordingly, it can be said that the origins of storytelling date back to very old times. In every culture and society, storytellers take different names such as shaman, meddah, kissahan, şehnamehan, mukallid, dengbej, minstrel, bard epic, story mother, story ancestor, nakkal, seanachaithe, rakugo, echo master and so on (Berlin, 2001; Topçam, 2019). The storyteller conveys events in words and 
images, often by improvising and embellishing. The training of the storyteller has been carried out in a master-apprentice relationship until this time, and the apprentice, growing up with a narrator, is encouraged by the master and passes the stories to other generations when the time comes. Nowadays storytelling education is carried out in the form of in-service training courses or short and long term workshops. We can show Argın Kubin, Şeyda Çevik and Aslı Hazar as examples to those who have recently adopted storytellingas a profession. At the Seiba International Storytelling Center founded by the storytellers Nazlı Çevik Azazi, Ayşe Senem Donatan and Şeyda Çevik who developed themselves in this field, professional storytellers are trained. Also "Basic Level Storytelling Trainer Training Course" was given for the first time in 2019 as an in-service training by the Ministry of National Education General Directorate of Teacher Training and Development with a goal to teach various methods and techniques related to storytelling to teachers in various branches who want to improve themselves in this field (MoNE, 2019).

In this sense, the main goal of this research is to find out whether the problem solving training providedthrough Drama Based Storytelling Method (DBSM) affects five-year-old children's problem solving skills. Accordingly, the following hypotheses will be tested:

1. Does the problem solving training provided through Drama Based Storytelling Method affect the problem solving skills of the five-year-old children?

2. Is the problem solving training provided through Drama Based Storytelling Method more effective in improving the problem solving skills of five-year-old children than the pre-school education program currently implemented?

3. Is the effect of problem solving training provided through Drama Based Storytelling Method permanent?

4. Does preschool education program that is currently implemented affect the problem solving skills of five-year-old children?

\section{Method}

\section{Research Design}

With an aim to examine the effect of problem solving training provided through DBSM, this study was done using quasi-experimental design, one of the quantitative research methods. In the quasiexperimental design, when the experimental and control groups are formed, forming groups from test subjects with similar characteristics rather than randomly chosen ones distinguishes this model from the true experimental design (Fraenkel \& Wallen, 2006; Stuart \& Rubin, 2007). In the research, pretest - posttest control group experimental design was used. The Scale of Problem Solving Skills (SPSS) was administered to both the experimental group and the control group just before and soon after the intervention program. A follow-up test was given to the experimental group two weeks after the post-test in order to determine the follow-up effect of the program. Personal Information Form was filled in for both groups after the study group was divided into experimental and control groups. Afterwards, the SPSS pre-test was administered individually to 40 children from experimental and control groups. MoNE Preschool Education Program was applied to control group. In addition to the MoNE Preschool Education Program, problem solving training provided through Drama Based Storytelling Method was given to the experimental group one hour two days a week for seven weeks. In the problem solving training provided through Drama Based Storytelling Method, 14 stories were told twice per week for seven weeks and the drama of these stories were acted out. The SPSS post-test was administered to experimental and control groups following the problem solving training. A follow-up test was administered to the experimental group 2 weeks following the SPSS post-test.

\section{Research Group}

Before starting the research, the proposal of the research was examined in terms of ethics at the Board of Directors of the Social Sciences Institute of Selcuk University and it was accepted on 18.04.2019. During 
this period, families of children who would continue the intervention program were interviewed and consent forms with wet signature were filled in. The study group consisted of five-year-old children who received pre-school education in a nursery class affiliated to a primary school in the central district of Selcuklu, Konya, in the fall semester of the 2018-2019 academic year. Multi-stage sampling was used when forming the sample. The multi-stage sampling method is defined as the sampling method in which the sampling process is completed in two or more stages (Büyüköztürk, 2013; Sedgwick, 2015). In the first stage, a nursery class affiliated to a primary school located in the central district of Selcuklu in Konya was selected by using the cluster sampling method, in which sample selection is made on a group basis. In the second stage, children were assigned to experimental and control groups based on their pre-test scores, considering their gender and age by using purposeful sampling. The researchers held a face-to-face meeting with the families of the children participating in the research group and made a commitment regarding ethical rules in this meeting. In this meeting, an agreement to participate in the research was signed with the parents of the experimental and control groups' children. A total of 40 children, 20 in the experimental group and 20 in the control group, were included in the study. All the participants had oneyear preschool education at the time.

The gender distribution of the children for both experimental and control groups was as follows: 12 $(60 \%)$ girls and $8(40 \%)$ boys for the experimental group, $11(55 \%)$ girls and $9(45 \%)$ boys for the control group. Considering the distribution of paternal educational background of the children in the experimental group, $5(25 \%)$ are university graduates, $8(40 \%)$ are high school graduates, $5(25 \%)$ are secondary school and $2(10 \%)$ are primary school graduates. As with the distribution of paternal educational background of the children in the control group, $6(30 \%)$ are university graduates, $7(35 \%)$ are high school graduates, 6 $(30 \%)$ are secondary school, and $1(5 \%)$ is primary school graduate. Overall, fathers in both groups showed varied educational backgrounds with 11 (27.5\%) university graduates, 15 (37.5\%) high school graduates, 11 (27.5) secondary school graduates and $3(7.5 \%)$ primary school graduates. Regarding the maternal educational backgrounds of the children in the experimental and control groups, 5 (25\%) are university graduates, $6(30 \%)$ are high school graduates, $7(35 \%)$ are secondary school, and $2(10 \%)$ are primary school graduates. Considering the maternal educational background of the children in the control group, $4(20 \%)$ are university graduates, $6(30 \%)$ are high school graduates, $8(40 \%)$ are secondary school, and $2(10 \%)$ are primary school graduates. Overall, mothers also had varied educational background with 9 (22.5\%) university graduates, 12 (30\%) high school graduates, 15 (37.5) secondary school graduates, and $4(10 \%)$ primary school graduates. In order to test whether the pre-test mean scores of the children in the experimental and control groups showed similarity, the pre-intervention mean scores of both groups were analyzed using the Mann Whitney $\mathrm{U}$ test.

Table 1. Mann Whitney U Test results related to pre-test scores of the experimental and control group

\begin{tabular}{|c|c|c|c|c|c|c|c|}
\hline Group & $\mathrm{n}$ & Mean Rank & $\begin{array}{l}\text { Sum of } \\
\text { Ranks }\end{array}$ & $\bar{x}$ & $\mathrm{sd}$ & $\mathrm{U}$ & $\mathrm{p}$ \\
\hline Experimental & 20 & 22.78 & 455.50 & 27.65 & 3.74 & 154.500 & .215 \\
\hline Control & 20 & 18.22 & 364.50 & 26.30 & 4.06 & & \\
\hline
\end{tabular}

According to Table 1, no statistically significant difference was found between the SPSS pre-test scores of the children in the experimental and control groups $(U=154.500, p>0.05)$. These values analyzed considering mean rank and sum of ranks indicated that pre-test scores of the experimental group children and the control group children were alike at baseline.

\section{The Drama Based Storytelling Method}

First of all, an extensive literature review was undertaken in Turkey (domestic) and abroad while the Drama Based Story-Telling Method was developed. The literature review indicated that various methods and techniques are used by enriching the contents of school programs in order to find alternative solutions to their problems in educational environments where children socialize. These methods and techniques contribute to the skill acquisition in children when applied at certain times. Especially in recent 
years, stories or fairy stories and drama have drawn attention among the methods used in developing problem solving skills. Based on this, 14 stories were written and drama plans were prepared for the animation of the stories by the researchers in accordance with the 18 problem situations in the SPSS. Stories were finalized following their analysis by a storyteller and a drama instructor made drama plans. The researchers informed the children in the pre-test process that they would do activities together. After pretest data was collected, problem-solving training was provided to the experimental group with the Drama Based Story-Telling Method, which was scheduled to be delivered in one-hour sessions two days a week for 7 weeks. 20 and 40 minutes were allocated for storytelling and drama respectively. Firstly, the stories were told by the researcher, and then the characters and their roles in the stories were acted out by the children. After the drama, feedback was provided along with the evaluations. One of the researchers, who applied the program, participated in the storytelling and drama training certificate programs.

This method is implemented in two stages:

Stage 1: The story is told following the preparation of the physical conditions and materials by the teacher or researcher.

- First of all, an atmosphere is prepared in accordance with the storytelling method that can attract the interest and attention of children. During the storytelling, materials to be used with the story are included; these materials can be story carpet, candle, puppets suitable for characters, musical instruments, rhythm sticks, mirrors and so on.

- Before starting the story, children are informed about the rhythm and repetitions used in the story. For example when the narrator says "trik" while opening the closed doors in the story, he asks children to say "trak" (Dede, 2017).

- Before the story, an imaginary cream is used to prepare the child's body for the story. The child's body, when applied this imaginary cream called invisibility cream, calms down and blood circulation slows down. Cream, being invisible, acts as a shield for the child to feel safe and to protect himself from all kinds of evils in adventures with story heroes.

- Before the story, a song or a nursery rhyme is sung to attract the attention of the children. Children focus on getting into the story and giving their full attention to the story along with the song or nursery rhyme. For example, "I peeled an orange, put it on my bedside, I made up a story, let the story hour begin. Tick, ticking, tick, ticking, let the story hour begin".

- A candle, lantern or oil lamp is used according to the preference of the narrator at the beginning and end of the story hour. These materials can be used when telling a story in this age group, as it shows the child the beginning and the end of the story concretely. For example, the child perceives that the time has started with the candle lit when the story begins, and when it is put out, he understands that the story ends.

- The narrator should adjust his tone of voice, gestures and mimics in accordance with the story by integrating with the story during the storytelling. The narrator may use a set of story phrases to attract the attention of the audience at the beginning, in the middle and at the end of the story. These include, for example, "Once upon a time", "Once there was", "Along time ago", "So, that is how the story ends", or "They lived happily ever after".

- The narrator actively engage children in the stories so that the ending of the story can be more effective and vivid in the children's minds. While the storyteller says "At that time, three apples fell from the sky; one for the children listening to the story, one for the storyteller who tells the story, and one for the heroes of the story", he may ask the children to hold and bite the apple by throwing the first imaginary apple. He can grab and bite the second apple himself and he may ask the children to grab the third apple and throw it to the heroes of the story. Thus, children will probably feel more joyful at the end of the story.

- After telling the story, the narrator asks questions so that the children can recognize the problematic behavior and asks them to tell events from their own lives. Then, preparations are made for 
the drama of the story.

Stage 2: Drama is created following the preparation of the physical conditions and materials by the teacher or researcher.

- The teacher is both the storyteller and the leader of the drama in the Drama Based Storytelling Method. The teacher guides the children to act out the story in accordance with the stages of the drama after the storytelling. Before the drama begins, costumes or masks that go with the characters, the story and the physical conditions suitable for the story can be created.

- In Drama Based Story Telling Method, the drama begins within the framework of drama plans in a way to be suitable for five-year-olds, and is prepared within the scope of the acquisition and indicators. The applied drama plans are prepared in a flexible way that may change depending on the attention span of the children and the conditions of the atmosphere.

- The first phase of the drama is warm-up. The warm-up is a phase in which the rules are determined by the leader and the rules are more distinct than those in other phases. The body goes into action heavily and the senses are used simultaneously. It is essential to create a group dynamic such as gaining confidence and adapting. At this stage, children's games or some invented games are used effectively. For example; finding one's partner, who has the hat, changing location by saying a name, who is missing, mirror and image are just a few of them. In addition, music and rhythm practices make it more fun by making it easier to warm up.

- The second phase of the drama is impersonation. This is the stage in which impersonations are made in certain stages within the framework of a subject or theme, determined in line with the goals the leader wants to achieve. While applying the Drama Based Story Telling Method, the stories written by the storyteller are animated at this stage. In this stage of the drama, improvisation and techniques of role playing are generally used more often. In accordance with the characters of the story, the roles are assigned starting first with the children who are eager or more enthusiastic to participate. The teacher, who takes on the leader role in the drama, just guides during the impersonation. He does not interfere with the children. Within the framework of the general plot in the stories, the children act out the story by emphasizing problem behaviors with sentences they use as improvisation at that moment.

- At the end of the impersonation phase, children find themselves in the relaxation stage, the third stage of the drama. Exercises for relaxation can be done physically, mentally and spiritually. At this stage, children relax their bodies, their minds and spiritually themselves through activities such as melting the snowman, pretending, lying on the floor and making some movements with instructions and music.

- The evaluation phase comes after the relaxation activity. In the evaluation phase, children sit on the floor by forming a semicircle under the leadership of the teacher. In the Drama Based Story Telling Method, discussions are held about how problem behaviors in the stories are reflected, how it feels to have a difficulty and what is felt while enacting these behaviors and how to find solutions to these problem behaviors. In addition, questions about warm-up and relaxation exercises are also asked.

\section{Data Collection Instruments}

"Personal Information Form" and "The Scale of Problem Solving Skills (SPSS)" developed by Oğuz and Köksal Akyol (2015) were used as data collection instruments in the research.

The Scale of Problem-Solving Skills (SPSS): The Scale of Problem Solving Skills (SPSS) is an instrument that aims to determine the problem-solving skills levels of children attending kindergarten classes. The SPSS includes eighteen problem situations and eighteen drawings relevant to these problem situations. The SPSS is rated on a five-point Likert-type scale. In the scale, points between " $0-4$ " are taken for the solution produced for each problem situation. Pointing system in the scale works as follow: " 0 " point for no suggestion, "1" point for one suggestion, "2" points for two suggestions, " 3 " points for three suggestions and "4" points for more than three suggestions. In order for the child to get points from the solutions he produces regarding the problem situation, each solution must be different from other solutions 
suggested. In practice, the child can repeat a solution he gives. Repeated solutions are not rated. The score to be obtained from the SPSS ranges between 0-72. Higher points in the SPSS represent better problem solving skills. In other words, the increase in the SPSS points of children shows that the child's problem solving skills have improved. In the SPSS, a child can get fifty points by responding to many problem situations. However, another child can get fifty points and produce a lot more alternative solutions, by responding to fewer questions. The important thing in the SPSS is that the child can produce more alternative solutions and the questions are only a tool. It does not matter which questions the child answers; the goal is the number of answers.

The validity of the scale was tested by means of the content-validity index and exploratory factor analysis. The reliability of the scale was tested through Cronbach's alpha internal consistency coefficient and test-retest reliability coefficient. The indexes were analyzed for two aspects: The appropriateness of the items and the appropriateness of the drawings. Finally, the content-validity indexes for the two aspects were 0.99 and 0.96 respectively. The exploratory factor analysis concluded that the SPSS had one-factor structure, which accounted for $30.68 \%$ of the total variance. Cronbach's Alpha Internal Consistency Coefficient was $\alpha=.86$. The Correlation Coefficient was .60, which was significant and moderate. The mean scores in the first and second administrations of the SPSS did not differ significantly. The validity and reliability analyses demonstrated that the SPSS is an appropriate instrument for children aged 60 to 72 months (Oğuz \& Köksal Akyol, 2015). The test was administered by the researcher. Each test took approximately 15 minutes to complete.

\section{Analysis of the Data}

In the research, the data obtained from the data collection instruments were analyzed using the Mann Whitney - U Test and Wilcoxon Signed Ranks Test. IBM SPSS 22.0 data analysis package program for social sciences was used for the data analysis. The reason for the use of nonparametric tests in the study is due to the fact that the data do not show normal distribution after normality test (Shapiro-Wilk Test, $\mathrm{p}<.05)$. Mann Whitney - U test was used to test whether the scores obtained from two unrelated groups differ significantly from each other and Wilcoxon signed ranks test was used to test the significance level of the difference between the scores of the associated measure set. Cohen's $d$ was calculated for the effect size between the means of problem solving skills scores. Cohen's $d$ is simply a measure used to determine the distance between two means. Regardless of its sign, Cohen's $d$ value is interpreted as small (.2), medium (.5) and large (.8) (Cohen, 1977, 1992).

\section{Results}

This research was undertaken to test whether the problem-solving training given through DramaBased Storytelling Method, the independent variable of the research, has an effect on the problem-solving skills of five-year-old children and in this part of the research, findings related to the sub-questions are presented.

\section{Findings Related to the SPSS Pre-Test and Post-Test Scores of the Experimental Group}

The difference between the SPSS pre-test and post-test scores of the experimental group children was analyzed with the Wilcoxon Signed Ranks Test and findings of the comparison were presented in Table 2.

Table 2. Wilcoxon Signed Ranks Test results and Cohen's d value related to the pre-test and post-test scores of the experimental group

\begin{tabular}{lcccccc}
\hline \multicolumn{1}{c}{ Group } & $\mathrm{n}$ & Mean Rank & Sum of Ranks & $\mathrm{z}$ & $\mathrm{p}$ & $d$ \\
\hline Negative Rank & 0 & .00 & .00 & $-3.923^{*}$ & $.000^{* *}$ & .70 \\
Positive Rank & 20 & 10.50 & 210.00 & & & \\
Equal & 0 & & & & & \\
\hline
\end{tabular}

*Based on negative ranks ${ }^{* *} \mathrm{p}<.001$

As seen in Table 2, a statistically significant difference exists between the SPSS pre-test and post-test 
scores of the experimental group children $(\mathrm{z}=3.923, \mathrm{p}<0.001)$. Considering the mean rank and sum of ranks, it can be said that the Drama Based Storytelling Method has an important effect on the development of the experimental group children's problem solving skills. In the analysis regarding the problem solving skills scores of the experimental group children, Cohen's $d$ value calculated for the group shows that the effect size is medium and explains $70 \%$ of the variability in the pretest and posttest scores.

\section{Findings Related to the Difference between the SPSS Post-Test Scores of the Experimental and Control Group}

The difference between the SPSS post-test scores of the children in the experimental and control groups was tested with the Mann Whitney $U$ test and the findings of the comparison were presented in Table 3.

Table 3. Mann Whitney U Test results and Cohen's d value related to the post-test scores of the experimental and control group

\begin{tabular}{lccccccc}
\hline Group & $\mathrm{n}$ & Mean Rank & $\begin{array}{c}\text { Sum of } \\
\text { Ranks }\end{array}$ & $\overline{\mathrm{x}}$ & $\mathrm{Sd}$ & $\mathrm{U}$ & $\mathrm{p}$ \\
\hline Experimental & 20 & 29.00 & 580.00 & 43.80 & 9.13 & 30.000 & $.000^{*}$ \\
Control & 20 & 12.00 & 240.00 & 29.85 & 3.58 & & \\
\hline${ }^{*} \mathrm{p}<.001$ & & & & &
\end{tabular}

In Table 3, a statistically significant difference is seen between the experimental and control group children's post-test scores on the SPSS $(\mathrm{U}=30.000, \mathrm{p}<0.001)$. Considering mean rank and sum of ranks, it was observed that the SPSS post-test mean score of the experimental group children receiving preschool education with Drama-Based Storytelling Method was higher than the SPSS post-test mean score of control group children who received the MoNE Preschool Education Program. In the analysis of the problem solving skills of children in the experimental and control groups, the Cohen's $d$ value calculated for the group shows that the effect size is medium, and being in different groups explains $70 \%$ of the variability in posttest scores.

\section{Findings Related the SPSS Follow-Up Test Scores of Experimental Group}

The difference between the SPSS post-test and follow up test scores of the experimental group children was tested with the Wilcoxon Signed Ranks Test and the findings of the comparison were presented in Table 4.

Table 4. Wilcoxon Signed Ranks Test results for the SPSS post-test and follow up test scores of experimental group

\begin{tabular}{|c|c|c|c|c|c|}
\hline Group & $\mathrm{N}$ & Mean Rank & Sum of Ranks & $\mathrm{z}$ & $\mathrm{p}$ \\
\hline Negative Rank & 7 & 5.71 & 40.00 & $-1.293^{*}$ & .196 \\
\hline Positive Rank & 3 & 5.00 & 15.00 & & \\
\hline Equal & 4 & & & & \\
\hline
\end{tabular}

As seen in Table 4, there is no statistically significant difference between the SPSS posttest and follow-up test scores of the experimental group children $(\mathrm{z}=1.293, \mathrm{p}>0.05)$. Considering the mean rank and sum of ranks, it is seen that there is no relation in the experimental group children in terms of post-test and follow up test scores. These results of the follow-up test shows that children in the experimental program maintained their skill development.

\section{Findings Related to the SPSS Pre-Test and Post-Test Scores of the Control Group}

The difference between the SPSS pre-test and post-test scores of the control group children was analyzed with the Wilcoxon Signed Ranks Test and the findings for comparison were presented in Table 5 . 
Gökhan KAYILI \& Zeynep ERDAL

Table 5. Wilcoxon Signed Ranks Test results and Cohen's d value related to the SPSS pre-test and post-test scores of the control group

\begin{tabular}{lcccccc}
\hline Group & $\mathrm{N}$ & Mean Rank & Sum of Ranks & $\mathrm{z}$ & $\mathrm{p}$ & $d$ \\
\hline Negative Rank & 1 & 9.50 & 9.50 & $-3.583^{*}$ & $.000^{* *}$ & .42 \\
Positive Rank & 19 & 10.55 & 200.50 & & & \\
Equal & 0 & & & & & \\
\hline
\end{tabular}

* Based on negative ranks ${ }^{* *} \mathrm{p}<.001$

The data in Table 5 shows that there is a statistically significant difference between the SPSS pre-test and post-test mean scores of the control group children $(\mathrm{z}=3.583, \mathrm{p}<0.001)$. Considering the mean rank and sum of ranks, it can be said that MoNE Pre-school Education Program currently implemented has an important effect on the development of problem solving skills of control group children. In the analysis regarding the problem solving skills scores of the control group children, Cohen's $d$ value calculated for the group shows that the effect size is medium and explains $42 \%$ of the variability in the pretest and posttest scores.

\section{Conclusion and Discussion}

General results obtained based on research findings are presented in this section. It is the aim of this research to examine the effect of problem solving training provided through Drama Based Storytelling Method on the problem solving skills of five-year-old children. A total of 40 children, 20 in the experimental group and 20 in the control group, were included in the research. The research adopted pre-test-posttest control group design. The follow up test was administered to the experimental group 2 weeks after the post tests and the permanence of the intervention was evaluated.

According to this research,

1. The problem solving training provided through Drama Based Storytelling Method affects the problem solving skills of five-year-old children.

2. The problem-solving training provided through Drama Based Storytelling Method is more effective than the MoNE preschool education program in improving the problem solving skills of five-year-old children.

3. The effect of problem solving training provided through Drama Based Storytelling Method is permanent.

4. MoNE Preschool Education Program affects the problem solving skills of five-year-old children.

In conclusion, the results of the research showed that problem solving training provided through Drama Based Storytelling Method implemented together with MoNE Preschool Education Program makes a positive contribution to the problem solving skills of five-year-old children and it is more effective than the MoNE Preschool Education Program. In addition, both the experimental group and the control group children's SPSS post-test scores are higher than their pre-test scores. This means there is an increase in the scores of both experimental and control group children. This is an indication that the MoNE Preschool Education Program makes positive contributions to the problem solving skills of five-year-old children. Graves, Frabutt, \& Vigliano (2007) found in their research that interpersonal problem-solving education given through drama and role-playing method increased the communication and social problem solving skills of primary and secondary school students. Drama and role playing have been used extensively in the drama-based storytelling method. The child can use all kinds of elements of communication in drama processes. Communication and sharing with individuals is the basis of drama. With this feature, drama requires using communication elements. Every stage of drama is based on verbal and non-verbal communication. In addition, drama allows the individual to realize and express his / her own thoughts, emotions and body in a free environment without worrying about being judged. These features of drama may have contributed to the development of communication skills of children participating in the intervention program and thus their interpersonal problem solving skills because the basis of interpersonal 
problem solving is to use the right communication methods (D'Zurilla, Nezu \& Maydeu-Olivares, 2004). Drama allows them to live by bringing the problems, situations and events in the social environment to the agenda of a certain group. The animation stage of the drama is based on the principle of using improvisation and role playing techniques, and the participants animate a topic individually, as a duo or as a group. The topics of drama usually include a problem, a conflict and tension. Animating different social problems, situations and events with drama method enables individuals to better understand the society and the relations in the society. This interaction allows individuals to examine appropriate and alternative solutions to social problems, to enact and to experience their results. Creative drama process helps individuals gain experience in solving problems (Önder, 2016). This feature of drama may have increased children's problem solving skills. Research has shown that sociodramatic play in early childhood classrooms increases opportunities for peer interaction and collaboration fosters healthy social and emotional development as children use drama to solve problems, deal with conflict, conquer fears, adopt new perspectives, regulate emotions, and practice self-regulation skills. Story dramas allow children to represent their ideas, feelings, and conflict resolution theories, as well as relate to other children's stories. These are many of the important skills needed to form a community (Curenton, 2006; Paley, 1990).

According to Webster-Stratton and Reid (2004), there are three different approaches to teaching children social problem solving skills. These are parent training, teacher training and child training which includes direct practices with children. Of these, child training is the most common approach and this can be achieved by means of preschool education programs. Today, there are many different types of preschool education programs. All known early childhood education programs intend to support all developmental areas of children. It is therefore one of the main goals of these programs to make children individuals who can solve their problems independently by supporting them in all developmental areas. Meta-analysis studies looking into the effectiveness of different training models designed to support children's problem solving skills indicate that these programs have created a significant impact on individuals. However, it is argued that combined programs or those implemented in an eclectic way have produced more effective outcomes compared to single programs (Anliak \& Dinçer, 2005). It is underlined in the literature that children participating in various programs in early childhood make good progress in their problem solving skills (Hutchings et al., 2011; Webster-Stratton, Reid \& Hammond, 2001). In this research, eclectic way (drama and storytelling) is considered a factor that increased the effectiveness of the program. Apart from that, the rituals of the storytelling method may have motivated the experimental group children.

Another factor thought to affect the research result is the use of drama method. The use of drama method for activities aimed at improving problem-solving skills enables the use of the problem solving steps by the experimental group children in different situations and influences the development of problem-solving skills. It is therefore suggested to provide the opportunity of using the problem-solving steps by organizing activities where problems encountered frequently in daily life are considered and also to support more active participation of the children in the problems that require solving social problems. However, role playing and improvisation are the basis of the techniques we use in drama education. In the stages of problem solving skill development, role playing and improvisation techniques in drama cover cognitive emotion and behaviors. We think that creating problems that include decision making and problem solving and animating them with improvisation and role-playing method contributes positively to children's problem-solving skills.

The advantages of Drama Based Storytelling Method in educational programs as prepared for children include promoting creative thinking, developing critical thinking, enhancing listening skills, improving the recognition of others and empathetic skills, developing collaboration with the group and respect for peers and supporting positive perspective towards oneself. Thus, problem solving skills of children are also supported (Köksal Akyol, 2018). In addition, children understand themselves, their friends, families and many aspects of the real life by creating, developing and reflecting in the drama and storytelling setting. Upon review of various social events, they start thinking about how people live and act under different conditions. They may bring forward different views and analyze personal views 
towards others. This will pave the way for children to dissent, discussion and solution (Fulford, Hutchings, Ross, \& Schmitz, 2001).

When the results of similar research on problem solving training provided through Drama Based Storytelling Method are examined, similar results have been obtained, supporting the findings of our research. Kayılı and Arı (2016) state that the presence of dramatic activities, puppets and stories that support conceptual development when used in social skills training programs are effective in the improvement of children's problem-solving skills. Başdaş (2017) examined the effect of the drama-based digital storytelling program on some social skills of 6-year-old children. A total of 48 children, 24 in the experimental and 24 in the control group, did warm-up exercises for the first two weeks and they were administered drama-based storytelling program three hours a week for the following 8 weeks. As a result of the research, a significant difference was observed in favor of the experimental group in sub-dimensions such as controlling anger behavior, adapting to changes, listening, creating goals and completing given tasks. Pekdoğan (2016) included 60 children (30 in experimental group, 30 in control group) in his research to examine the effect of the Story-Based Social Skills Education Program on the improvement of social skills of 5-6 year-old preschool children. Story-Based Social Skills Training Program was provided to the children in the experimental group twice a week for 5 weeks. The results showed that there was a significant difference in the social skill scores between the experimental and the control group and the effect of the training program continued. Alemdar Coşkun (2016) included 66 children in her research in order to examine the effect of the Problem Solving Training Program on problem solving skills and interpersonal problem solving skills of kindergartners. During the research process, the Problem Solving Education Program prepared by the researcher was applied to 22 children in the experimental group 3 days a week for 8 weeks. It was found that the post-test scores were higher than the pre-test scores of the children in the experimental group in sub-dimensions such as realizing the problem, defining the problem, asking questions, guessing the reason, deciding the adequacy of the information for the solution, defining the elements of the problem, using objects in a different way, predicting the outcome of some actions, finding the most appropriate solution and choosing the most unusual solution among many possible solutions. Besides, skills like understanding and defining a problem, collecting necessary information to solve the problem, determining the solution to the problem, choosing the most appropriate solution for the problem, applying the solution determined for the problem, solving and evaluating the problem and interpersonal problem-solving skills can also be improved with educational programs that support children's problemsolving skills.

\section{Recommendations}

The effect of the drama-based storytelling method on problem solving skills can be examined in new studies with larger sample groups and more children. This can be considered a limitation of the current research. The results obtained in our research have revealed the short-term effects of the training program. More studies therefore can be conducted to explore the long-term effects of the training program. The purpose of this research was to improve the problem solving skills of five-year-old children by developing the Drama Based Storytelling Method and providing problem solving training. Different skill areas can be supported by providing training for these skill areas using the same method in future research. This research was conducted with children of 5 years age group. The follow-up effect of the Drama Based Storytelling Method can be tested in younger or older age groups in different research studies. In our study, an education program was prepared in a way that the method of storytelling and drama support each other. A training program can be prepared by combining the storytelling method with different methods in future research. The effect of the storytelling method on the MoNE Preschool Education Program was analyzed. A research study can also be undertaken to compare storytelling method with different methods in future studies.

In the preschool period, drama practices are applied within the framework of certain rules and stages and they are included in the national preschool education program. Based on this, stories can be told according to certain rules within the framework of the concept of "Storytelling" in the national preschool 
education program and some stages which teachers can apply collaboratively can be included. In-service training related to "Storytelling" can be popularized by the Ministry of National Education. "Storytelling" classes can be added to educational programs in order for pre-service teachers to improve themselves or workshops can be created in undergraduate programs of universities. These trainings can be provided for students by establishing "Storytelling Workshops" in educational institutions.

\section{Declarations}

Acknowledgements: We would like to thank the experimental and control group children, teachers and families for their participation and cooperation.

Authors' contributions: Author 1 is the senior and corresponding author of this manuscript. Research concept and design: Author 1. Statistical analysis: Author 1. Research supervision: Author 1. Drafting of the manuscript: Author 2. Collecting data: Author 2. Implementing the experimental program: Author 2. Preparation of experimental program: All authors. All authors wrote and reviewed the manuscript.

Competing interests: The authors declare that they have no competing interests.

Funding: This research was not supported by any funding.

\section{References}

Adıgüzel, H. Ö. (2013). Eğitimde yaratıcı drama. Ankara: Pegem Akademi.

Alemdar Coşkun, M. (2016). Problem çözme eğitim programının anasınıfına devam eden çocukların problem çözme becerileri ile kişiler arası problem çözme becerilerine etkisi (Unpublished Doctoral Dissertation). Gazi University Institute of Educational Sciences, Ankara.

Anlıak, Ş., \& Dinçer, Ç. (2005). Developing interpersonal cognitive problem solving skills in preschool period. Eurasian Journal of Educational Research, 20, 122-134.

Bash, M. A. S., \& Camp, B. W. (1985). Think aloud: Increasing social and cognitive skills- A problem solving program for children in the classroom. London: Research Press Pub.

Başdaş, F. (2017). Drama temelli hikaye anlatıcılı̆̆ı programının 6 yaş çocuklarının bazı sosyal becerilerinin gelişimine etkisi (Unpublished Master Thesis). Adnan Menderes University Institute of Social Sciences, Aydın.

Battistich, V., Schaps, E., \& Wilson, N. (2004). Effects of an elementary school intervention on students' "connectedness" to school and social adjustment during middle school. The Journal of Primary Prevention, 24(3), $243-262$. https://doi.org/10.1023/B:JOPP.0000018048.38517.cd

Beelmann, A., Pfingsten, U., \& Lösel, F. (1994). Effects of training social competence in children. A meta-analysis of recent evaluation studies. Journal of Clinical Child Psychology, 23(3), 260-271. https://doi.org/10.1207/s15374424jccp2303_4

Berlin, A. (2001). The book of Esther and ancient storytelling. Journal of Biblical Literature, 120(1), 3-14. https://doi.org/10.2307/3268590

Bingham, A. (1998). Çocuklarda problem çözme yeteneklerinin geliştirilmesi. İstanbul: Milli Eğitim Yayınevi.

Bolton, G. (2007). A History of drama education: A search for substance. In Bresler L. (Ed.), International handbook of research in arts education. 45-62, Springer, Dordrecht. https://doi.org/10.1007/978-1-4020-3052-9 4

Boratav, P. N. (2019). 100 Soruda Türk halk edebiyatı. (5th ed.). Ankara: Bilge Su Yayıncilık.

Brown, W. H., Odom, S. L., \& McConnell, S. R. (2008). Social competence of young children: Risk, disability, and intervention. Baltimore, MD: Brookes.

Büyüköztürk, Ş. (2013). Sosyal bilimler için veri analizi el kitabı. Ankara: Pegem Akademi.

Clark, L. A., Cuthbert, B., Lewis-Fernández, R., Narrow, W. E., \& Reed, G. M. (2017). Three approaches to understanding and classifying mental disorder: ICD-11, DSM-5, and the National Institute of Mental Health's Research Domain Criteria (RDoC). Psychol Sci Public Interest, 18(2), 72-145. https://doi.org/10.1177/1529100617727266

Cohen, J. (1977). Statistical power analysis for the behavioral sciences. New York: Academic Press. https://onlinelibrary.wiley.com/doi/epdf/10.1002/nur.20247

Cohen, J. (1992). A power primer. Psychological Bulletin, 112(1), 155-159. https://doi.org/10.1037/0033-2909.112.1.155

Curenton, S. (2006). Oral storytelling: A cultural art that promotes school readiness. Young Children, 61(5), $78-87$.

Çavuş, Ş. (2004). Problem çözme becerisinin temel felsefesi. Journal of Kazım Karabekir Education Faculty, 10, 160-171.

Dede, A. (2017). Hadi masal anlatalım. İstanbul: Taze Kitap.

Durlak, J. A., Weissberg, R. P., Dymnicki, A. B., Taylor, R. D., \& Schellinger, K. B. (2011). The impact of enhancing students' social and 
emotional learning: A meta-analysis of school-based universal interventions. Child Development, 82(1), 405-432. https://doi.org/10.1111/j.1467-8624.2010.01564.x

D’Zurilla, T. J., Nezu, A. M., \& Maydeu-Olivares, A. (2004). Social problem solving: Theory and assesment. In E. Chang, T. J. D’Zurilla, \&L. J. Sana, (Eds.), Social problem solving: Theory, research and training (pp. 3-27). Washington DC: American Psychological Association.

Erdoğan, T. (2019). Okul öncesinden ilköğretime kuramdan uygulamaya drama. Ankara: Eğiten Kitap.

Fraenkel, J. R., \& Wallen, N. E. (2006). How to design and evaluate research in education (6th ed.). New York, NY: McGraw-Hill.

Fulford, J., Hutchings, M., Ross, A., \& Schmitz, H. (2001). Drama in elementary education. (L. Küçükahmet, H. Borçbakan, \& S. S. Karamaoğlu, Trans.). Ankara: Nobel Publication Distribution.

Gardner, R., Cartledge, G., Seidl, B., Woolsey, L., \& Schley, G. (2001). The Mt. Olivet after-school program: An alternative intervention for at-risk students. Remedial and Special Education, 22(1), 22-33. https://doi.org/10.1177/074193250102200104

Goldstein, A. P., \& Pentz, M. (1984). Psychological skills training and the aggressive adolescent. School Psychology Review, 13(3), 311323. https://doi.org/10.1080/02796015.1984.12085108

Goodman, S. H., Gravitt, G., \& Kaslow, N. J. (1995). Social problem solving: A moderator of the relation between negative life stress and depression symptoms in children. Journal of Abnormal Child Psychology, 23(4), 473-485. https://doi.org/10.1007/BF01447209

Graves, K. N., Frabutt, J. M., \& Vigliano, D. (2007). Teaching conflict resolution skills to middle and high school students through interactive drama and role play. Journal of School Violence, 6(4), 57-80. https://doi.org/10.1300/J202v06n04_04

Heppner, P. (1987). An infofmation processing apporach to personal problem solving. The Counseling Psychologist, 15(3), 34-37. https://doi.org/10.1177/0011000087153001

Hutchings, J., Bywater, T. J., Gridley, N., Whitaker, C. J., Martin-Forbes, P., \& Gruffydd, S. (2011). The incredible years therapeutic social and emotional skills programme: A pilot study. School Psychology International, 33(3), $285-293$. https://doi.org/10.1177/0143034311415899

Kayıll, G., \& Arı, R. (2016). The effect of Montessori Method supported by social skills training program on Turkish kindergarten children's skills of understanding feelings and social problem solving. Journal of Education and Training Studies, 4(12), 81-91. https://doi.org/10.11114/jets.v4i12.1965

Kneeland, S. (2001). Problem solving (N. Kalayc1, Trans.). Ankara: Gazi Publishing.

Köksal Akyol, A. (2018) Examination of the effect of drama education on multiple intelligence areas of children. Early Child Development and Care, 188(2), 157-167. https://doi.org/10.1080/03004430.2016.1207635

Mayeux, L., \& Cillessen, A. H. (2003). Development of social problem solving in early childhood: Stability, change, and associations with social competence. The Journal of Genetic Psychology, 164(2), 153-173. https://doi.org/10.1080/00221320309597975

Ministry of National Education [MoNE]. (2013). Preschool education program. Retrieved December 15, 2019, from http://tegm.meb.gov.tr/dosya/okuloncesi/ooproram.pdf

$\begin{array}{llllll}\text { Ministry of } & \text { National } & \text { Education } & \text { (2019). } & \text { Anatolian } & \text { stories. }\end{array}$ https://cdn2.eba.gov.tr/PROD REPOSITORY/8/848393e4ab12b4d3ffe2a2fa09617677.pdf?st=zsXPTiysH5VdEOACPPpsBA\&e $=1593560410$ accessed from web site on March 2, 2020.

Oğuz, V., \& Köksal Akyol, A. (2015). Problem Çözme Becerisi Ölçeği (PÇBÖ) geçerlik ve güvenirlik çalişmasi. Çukurova University Journal of Education Faculty, 44(1), 105-122. https://doi.org/10.14812/cufej.2015.006

Önder, A. (2016). Yaşayarak öğrenme için eğitici drama kuramsal temellerle uygulama teknikleri ve örnekleri (10 ${ }^{\text {th }}$ ed.). Ankara: Nobel Yayın Dağıtım.

Paley, V. G. (1990). The boy who would be a helicopter: The use of storytelling in the classroom. Cambridge: Harvard University Press.

Pekdoğan, S. (2016). Investigation of the effect of story-based social skills training program on the social skill development of 5-6 yearold children. Education and Science, 41(183), 305-318.

Powell, C. (2020). "Acting a play helped me." Year 8 students' understanding, inclusion and empowerment whilst using dramafocused collaborative learning to explore A MidSummer Night's Dream. English in Education, https://doi.org/10.1080/04250494.2020.1816135

Ritter, S. M., \& Mostert, N. (2017). Enhancement of creative thinking skills using a cognitive-based creativity training. Journal of Cognitive Enhancement, 1, 243-253. https://doi.org/10.1007/s41465-016-0002-3

Sakaoğlu, S. (2016). Masal araştırmaları. (7th ed.). Ankara: Akçağ Yayınları.

Sağlam, T. (1997). Eğitimde drama ve Türk çocuklarının ritüel nitelikli oyunlarının eğitimde dramada kullanımı. (Doctoral Dissertation). Ankara University Institute of Social Sciences, Ankara. 
Schneider, B. H. (1992). Didactic methods for enhancing children's peer relations: A quantitative review. Clinical Psychology Review, 12(3), 363-382. https://doi.org/10.1016/0272-7358(92)90142-U

Sedgwick, P. (2015). Multistage sampling, BMJ, 351, 41-55. https://doi.org/10.1136/bmj.h4155

Shure, M. B. (2001). I can problem solve (ICPS): An interpersonal cognitive problem solving program for children, Residential Treatment for Children \& Youth, 18(3), 3-14. https://doi.org/10.1300/I007v18n03 02

Stuart, E. A., \& Rubin D. B. (2007). Best practices in quasi-experimental designs: Matching methods for causal inference. In Jason Osborne (Ed.), Best practices in quantitative methods (pp. 155-176). New York: Sage. https://doi.org/10.4135/9781412995627.d14

Szecsi, T. (2008). Teaching strategies: Creative drama in preschool curriculum: Teaching strategies implemented in Hungary. Childhood Education, 85(2), 120-124. https://doi.org/10.1080/00094056.2009.10523078

Topçam, S. (2019). Masal anlatıcllğ̆ı ve günümüz masal anlatıcllı̆̆ında hazırlanma süreçleri (Unpublished Master Thesis). Dokuz Eylül University Institute of Fine Arts, İzmir.

Webster, D. (2010). Promoting empathy through a creative reflective teaching strategy: A mixed-method study. Journal of Nursing Education, 49(2), 87-94. https://doi.org/10.3928/01484834-20090918-09

Webster-Stratton, C. (2012). Incredible teachers: Nurturing children's social, emotional and academic competence. West Seattle: Incredible Years Inc.

Webster-Stratton, C., \& Reid, M. J. (2004). Strengthening social and emotional competence in young children-The foundation for early school readiness and success, incredible years classroom social skills and problem-solving curriculum. Infants and Young Children, 17(2), 96-113. https://doi.org/10.1097/00001163-200404000-00002

Webster-Stratton, C., Reid, M. J., \& Hammond, M. (2001). Preventing conduct problems, promoting social competence: A parent and teacher training partnership in Head Start. Journal of Clinical Child Psychology, 30(3), $283-302$. https://doi.org/10.1207/S15374424JCCP3003 2

Weissberg, R. P., Kumpfer, K. L., \& Seligman, M. E. P. (2003). Prevention that works for children and youth: An introduction. American Psychologist, 58(6/7), 425-432. https://doi.org/10.1037/0003-066X.58.6-7.425

Yeates, K. O., Schultz, L. H., \& Selman, R. L. (1991). The development of interpersonal negotiation strategies in thought and action: A social-cognitive link to behavioral adjustment and social status. Merrill-Palmer Quarterly, 37(3), 369-407. 